\title{
Neospora caninum and Toxoplasma gondii serodiagnosis in human immunodeficiency virus carriers
}

\author{
Leandra Marla Oshiro[1], Ana Rita Coimbra Motta-Castro ${ }^{[2]}$, \\ Solange Zacalusni Freitas ${ }^{[2]}$, Rodrigo Casquero Cunha ${ }^{[3]}$, \\ Rosangela Locatelli Dittrich ${ }^{[4]}$, Andréa Christine Ferreira Meirelles ${ }^{[5]}$ \\ and Renato Andreotti ${ }^{[6]}$
}

[1]. Programa de Graduação em Doenças Infecciosas e Parasitárias, Universidade Federal de Mato Grosso do Sul, Campo Grande, Mato Grosso do Sul, Brazil. [2]. Curso de Farmácia Bioquímica, Universidade Federal de Mato Grosso do Sul, Campo Grande, Mato Grosso do Sul, Brazil. [3]. Departamento de Biotecnologia, Universidade Federal de Pelotas, Pelotas, Rio Grande do Sul, Brazil. [4]. Departamento de Medicina Veterinária, Universidade Federal do Paraná, Curitiba, Paraná, Brazil. [5]. Pontifícia Universidade Católica do Paraná, Toledo, Paraná, Brazil. [6]. Laboratório de Biologia Molecular, Sanidade Animal, Embrapa Gado de Corte, Campo Grande, Mato Grosso do Sul, Brazil.

\begin{abstract}
Introduction: Neospora caninum and Toxoplasma gondii belong to the Sarcocystidae family, and both have one definitive and various intermediary hosts. Owing to their weak immune systems, immunocompromised persons might be prone to opportunistic infections. The aim of this study was to investigate the presence of anti- $N$. caninum and anti-T. gondii antibodies in immunocompromised individuals. Methods: This cross-sectional study investigated the rates of $N$. caninum and T. gondii, as assessed using immunofluorescent antibody reaction (IFAT) with 1:50 and 1:16 dilution, respectively, in patients with human immunodeficiency virus (HIV). Results: The seropositivity for $N$. caninum was $26.1 \%$ (81/310) in Mato Grosso do Sul and 31.2\% (10/32) in Paraná and for T. gondii was 76.8\% (238/310) in Mato Grosso do Sul and 68.7\% (22/32) in Paraná. Conclusions: There is evidence of anti- $N$ caninum and anti- $T$. gondii antibodies in patients with HIV. Other aspects of $T$. gondii, which is a zoonosis, and $N$. caninum, which might affect immunodeficient individuals, need to be evaluated and reported.
\end{abstract}

Keywords: Serology. Toxoplasma gondii. Neospora caninum. HIV.

\section{INTRODUCTION}

Since $2009^{(1)}$, there have been reports of opportunistic protozoan infections in immunocompromised patients. Owing to their inability to control parasite replication, clinical disease can occur, resulting in morbidity and mortality.

Following the first description of acquired immune deficiency syndrome (AIDS) in the 1980s, it has become one of the most researched diseases owing to its pandemic nature and severity. It is characterized by immune system suppression, primarily the immunity mediated by $\mathrm{T}$ cells; the decline of cluster of differentiation 4 (CD4) lymphocytes results in susceptibility to opportunistic infections, secondary neoplasms, and neurological diseases ${ }^{(2)}$.

Corresponding author: Dr. Renato Andreotti. Lab. Biologia Molecular/ Sanidade Animal/Embrapa Gado de Corte. Av. Rádio Maia, Vila Popular, 79106-550 Campo Grande, Mato Grosso do Sul, Brasil.

Phone: 5567 3368-2173; Fax: 5567 3368-2150

e-mail: renato.andreotti@embrapa.br

Received 8 May 2015

Accepted 23 July 2015
Neospora caninum and Toxoplasma gondii are intracellular protozoans belonging to the Sarcocystidae family that can infect domestic and wild animals. Both are parasites that cause cyst formation and have in their definitive host cycle a carnivorous animal and a wide variety of species as their intermediary hosts $^{(3)}$.

Because it is a zoonosis, T. gondii is considered an important parasite in both human and veterinary medicine. The felid, which is an important host in the T. gondii lifecycle, is responsible for parasite dissemination, by introducing the oocyst in the environment. The intermediary host acquires toxoplasmosis through contaminated food and water ${ }^{(4)}$.

Neospora caninum was identified in 1984 by Bjerkas et al. ${ }^{(5)}$, before which time it was confused with $T$. gondii. When infected with $N$. caninum, some canids (dogs, dingoes, and coyotes) can become a definitive host and develop neurological problems. $N$. caninum is also known to cause reproductive problems, such as abortions and stillbirths, in production animals (bovines, caprines, and ovines) $^{(6)}$.

Toxoplasmosis is disseminated in various parts of the world and affects both humans and animals, with at least two billion infected people. In humans, the possibility of acquiring the disease is higher with age; its frequency varies depending on the population and geographical location and is lower 
in colder locations ${ }^{(7)}$. The symptoms in immunocompetent humans are usually not apparent. However, symptoms of headaches, paralysis, and mental deterioration can present in immunocompromised patients, such as carriers of human immunodeficiency virus (HIV); these clinical symptoms are also common to various other opportunistic parasites ${ }^{(8)}$.

Different methods are available to diagnose $N$. caninum and T. gondii, including direct methods, such as histopathological, immunohistochemical, or polymerase chain reaction (PCR) procedures, as well as indirect methods, such as enzymelinked immunosorbent assay (ELISA), agglutination test, and immunofluorescent antibody reaction (IFAT) procedures. The latter is the technique of reference for $N$. caninum $^{(9)(10)}$.

The presence of anti-N. caninum antibodies in humans was detected in 1999 based on the analysis of 1,029 samples from the California blood bank ${ }^{(11)}$. Although 69 samples were positive on the IFAT test, 50 samples did not have $T$. gondii antibodies. In the same year, Peterson et al. ${ }^{(12)}$ analyzed samples from 76 women with a history of abortion or intrauterine fetal death in Denmark, without detection of anti- $N$. caninum antibodies. However, the authors did not discard the possibility of a parasite infection and proposed that patients with neurological problems of unknown causes and immunocompromised patients should be examined.

In 2002, Magalhães et al.(13) analyzed blood samples from three groups, including a group of patients with HIV, in Bahia and found positive serological reactions in all groups. In Minas Gerais (MG) in 2006, positive samples were found for HIVpositive patients with neurological problems, newborns, and individuals considered to be healthy, with the group of HIV patients having the highest percentage, at $38 \%^{(14)}$.

There is no evidence that $N$. caninum infection is zoonotic ${ }^{(15)}$; however, these reports of seropositivity in humans do not allow us to discard the possibility that the parasitic infection affects human beings ${ }^{(11)(16)}$. Humans might become infected with $N$. caninum in the same way as with $T$. gondii, by the accidental ingestion of oocysts found in the feces of the definitive host, the canid, and also by the consumption of badly cooked or raw meat containing cysts from the intermediary hosts ${ }^{(17)}$.

In Brazil, serological studies of neosporosis and toxoplasmosis in human beings are scarce; this is also true in Mato Grosso do Sul (MS), where reports of anti-T. gondii antibodies are limited to university students and newborns in Campo Grande, the population from Pantanal, and the indigenous population of the Miranda county in the State of MS, which is the most recently reported study ${ }^{(18)(19)(20)(21)(22)}$.

Considering the close interaction between people and seropositive animals via animal management and the cooking and ingestion of raw or badly cooked meat as well as the impaired immunity of immunocompromised individuals, such as HIV carriers and patients with neoplasia, a serological study of immunocompromised patients is the first step to evaluate the possibility of a $N$. caninum infection in humans in MS. Therefore, owing to its importance and the shortage of information regarding these parasites in humans in the States of Mato Grosso do Sul and Paraná (PR), the aim of this study was to investigate the presence of anti- $N$. caninum and anti-T. gondii antibodies in immunocompromised individuals using the IFAT method.

\section{METHODS}

A cross-sectional study involving $310 \mathrm{HIV}$-positive patients in two reference centers in Campo Grande-MS was conducted between November 2009 and June 2011 [Research Ethics Committee, Comitê de Ética em Pesquisa/Universidade Federal de Mato Grosso do Sul (CEP/UFMS) 1941/11]. In the State of PR, 32 HIV-positive patients, people who have agreed to be part of the survey, were selected from the serology lab of the Erasto Gaertner Hospital to be tested using chemiluminescence (Jonhson \&d Jonhson do Brasil Ltda, Brazil) between August 2012 and August 2013 [Research Ethics Committee Comitê de Ética em Pesquisa/Pontificia Universidade Católica do Paraná (CEP/PUCPR) 5017/11].The sample sizes differed between MS and PR because of sample availability and the granted access to data for the researchers. The patients provided consent to participate and signed the Terms of Consent.

The cephalic vein was accessed for sample collection by a healthcare professional; $10 \mathrm{~mL}$ samples were collected from either the right or left cephalic vein, equally divided in tubes without anticoagulant, and duly identified. After collection, the tubes were rested at room temperature and protected from light for clot retraction. Then, the tubes were centrifuged for blood serum, which was stored in microtubes and kept at $-20^{\circ} \mathrm{C}$ until the serological exams.

\section{Immunofluorescent antibody reaction for the detection of anti-Neospora caninum and Toxoplasma gondii antibodies}

Serum samples were tested for immunoglobulin $\mathrm{G}(\operatorname{IgG})$ anti- $N$. caninum (NC-1 strain) and T. gondii (RH strain) using the IFAT method. Serum samples were tested at an initial dilution of 1:50 and 1:16 in phosphate buffered saline (PBS) solution (pH 7.2) for $N$. caninum and T. gondii, respectively, and the positives were diluted to an endpoint titer(i.e., the test was conducted again with an increased dilution until the fluorescence ceased to be present over the whole parasite). The IFAT technique and the slides for IFAT were prepared according to the method by Locatelli-Dittrich ${ }^{(23)}$. Bovine serum samples, knowingly positive or negative, were used as controls for all slides. The fluorescent conjugate human anti-IgG or bovine anti-IgG were used with a dilution of 1:100 (conjugate with fluorescein isothiocyanate [SIGMAC]). The slides were observed using a microscope equipped for fluorescence (epi-illumination system), with an objective of $40 \times$. Fluorescent reactions around the entire periphery of the parasite were considered positive. In negative reactions, the parasites on the slide did not present fluorescence, or the fluorescence was located only on one end, characterized as polar coloration or apical reaction. Samples with total tachyzoite peripheral fluorescence were considered positive ${ }^{(24)}$.

\section{Statistical analysis}

The results of the serological exams were statistically analyzed using the $\chi^{2}$ test using Medcalc statistical package 
and level of significance of $p>0.05$. Demographic data such as sex, ethnicity, education, and income as well as some of the risk factors such as surgery, blood transfusion, tattoos, and presence of other diseases were also analyzed within and between the surveyed parasites using $\chi^{2}$ tests.

\section{RESULTS}

The patients were mostly $(54.5 \%)$ male, white, with a primary education, with an income between 1 and 3 minimum salaries (currently, the minimum salary in Brazil is of $\mathrm{R} \$ 788,00$ ), and born in the State of MS.

Anti-Neospora caninum antibodies were detected in $26.1 \%$ $(81 / 310)$ of the samples with a 1:50 dilution from HIV-positive patients in MS; with a 1:400 dilution, only 1 patient was considered positive (Table 1). In PR, 32 samples from HIVpositive patients were analyzed, and 10 individuals were found with anti- $N$. caninum antibodies (31.2\%).

Anti-T. gondii antibodies were detected in 76.8\% (238/310) of the samples with a 1:16 dilution from HIV-positive patients in MS; with a 1:2,048 dilution, only 4 patients were considered positive (Table 2). Anti-T. gondii antibodies were detected in $68.7 \%(22 / 32)$ of the samples from HIV-positive patients in the State of PR.

Demographic analysis as sex and education was not significant with $p>0: 05$ and risk factors such as diseases, acupuncture, surgery also was not significant

Based on the $\chi^{2}$ test (Table 3), of the 310 samples from the HIV-positive patients, 81 (26.1\%) were positive for $N$. caninum.
TABLE 1 - Presence of Neospora caninum in the serum of human immunodeficiency virus-positive patients in Mato Grosso do Sul.

\begin{tabular}{|c|c|c|c|}
\hline \multicolumn{4}{|c|}{ Neospora caninum } \\
\hline $\begin{array}{c}\text { IFAT } \\
(1: 50) \\
+/ \%\end{array}$ & $\begin{array}{c}\text { IFAT } \\
(1: 100) \\
+/ \%\end{array}$ & $\begin{array}{c}\text { IFAT } \\
(1: 200) \\
+/ \%\end{array}$ & $\begin{array}{c}\text { IFAT } \\
(1: 400) \\
+/ \%\end{array}$ \\
\hline $81 / 26.1$ & $6 / 1.9$ & $2 / 0.6$ & $1 / 0.3$ \\
\hline
\end{tabular}

HIV: human immunodeficiency virus; IFAT: immunofluorescence assay; +: sample positive; $\%$ : percentage of sample positive.

HIV-positive patients who were not on dialysis treatment had a significantly higher probability of being infected with N. caninum $(\mathrm{p}<0.05)$.

Continuing the analysis (Table 4) in the same population, $238(76.8 \%)$ positive samples $(\mathrm{p}<0.0001)$ from the $T$. gondii serology were detected.

Coinfection was present (Table 3), with 78 (25.2\%) of the $238 \mathrm{~N}$. caninum-positive samples also positive for $T$. gondii $(\mathrm{p}<0.0001)$.

\section{DISCUSSION}

In the State of MS $(\mathrm{n}=310)$ and $\mathrm{PR}(\mathrm{n}=32)$, seropositivities for $N$. caninum were $26.1 \%$ and $31.2 \%$, respectively, in HIV-positive individuals. Comparatively, the previously

TABLE 2 - Presence of Toxoplasma gondii in the serum of human immunodeficiency virus-positive patients in Mato Grosso do Sul.

\begin{tabular}{|c|c|c|c|c|c|c|c|c|c|}
\hline & \multicolumn{9}{|c|}{ Toxoplasma gondii } \\
\hline HIV & 310 & $238 / 76.8$ & $141 / 45.5$ & $128 / 41.3$ & $113 / 36.5$ & $75 / 24.2$ & $17 / 5.5$ & $8 / 2.6$ & $4 / 1.3$ \\
\hline
\end{tabular}

HIV: human immunodeficiency virus; IFAT: immunofluorescence assay; +: sample positive; \%: percentage of sample positive.

TABLE 3 - Analysis of the results of Neospora caninum samples using the $\chi^{2}$ test.

\begin{tabular}{|c|c|c|c|c|c|c|c|c|c|}
\hline \multirow{3}{*}{\multicolumn{2}{|c|}{ Risk factors or characteristics }} & \multicolumn{6}{|c|}{ Neospora caninum } & \multirow{3}{*}{ Chi-square } & \multirow{3}{*}{ p-value } \\
\hline & & \multicolumn{2}{|c|}{ positive } & \multicolumn{2}{|c|}{ negative } & \multicolumn{2}{|c|}{ total } & & \\
\hline & & $\mathbf{n}$ & $\%$ & $\mathbf{n}$ & $\overline{\%}$ & $\mathbf{n}$ & $\%$ & & \\
\hline HIV reactive & & 81 & 26.1 & 229 & 73.9 & 310 & 100.0 & 69.7 & $<0.0001$ \\
\hline Patients on dialysis & 1 & 76 & 24.5 & 226 & 72.9 & 302 & 97.4 & 3.9 & 0.0495 \\
\hline Toxoplasma gondii & Negative & 3 & 1.0 & 69 & 22.3 & 72 & 3.2 & & \\
\hline
\end{tabular}

HIV: human immunodeficiency virus; IFAT: immunofluorescence assay; +: sample positive; $\%$ : percentage of sample positive; $\chi 2$ : the $\chi 2$ test using Medcalc statistical package and level of significance of $\mathrm{p}>0.05$. 
TABLE 4 - Analysis of the results of Toxoplasma gondii samples using the $\chi^{2}$ test.

\begin{tabular}{|c|c|c|c|c|c|c|c|c|}
\hline \multirow{3}{*}{ Risk factors or characteristics } & \multicolumn{6}{|c|}{ Toxoplasma gondii } & \multirow{3}{*}{$\chi^{2}$} & \multirow{3}{*}{ p-value } \\
\hline & \multicolumn{2}{|c|}{ positive } & \multicolumn{2}{|c|}{ negative } & \multicolumn{2}{|c|}{ total } & & \\
\hline & $\mathbf{n}$ & $\%$ & $\mathbf{n}$ & $\%$ & $\mathbf{n}$ & $\%$ & & \\
\hline HIV reactive & 238 & 76.8 & 72 & 23.2 & 310 & 100.0 & 87.8 & $<0.0001$ \\
\hline
\end{tabular}

HIV: human immunodeficiency vírus; $\chi 2$ : the $\chi 2$ test using Medcalc statistical package and level of significance of $\mathrm{p}>0.05$.

reported rates of positivity for class IgG antibodies were $38 \%$ in 65 HIV-positive individuals in the State of MG, using the same serological test and dilution $(1: 50)^{(14)}$ and $15 \%$ in individuals with HIV, 3.8\% in healthy individuals, and 5\% in women (with or without previous abortions) ( $\mathrm{n}=80 \mathrm{each})$ in Bahia, detected using IFAT ${ }^{(13)}$. Seropositivity of anti- $N$. caninum antibodies was detected in 7 serum samples (10.5\%) from 67 rural workers on farms with serologically positive bovines and dogs in the State of Mato Grosso (MT), Brazil ${ }^{(24)}$.

The seropositivities for T. gondii in the States of MS and PR in the present study were $76.8 \%$ and $68.7 \%$, respectively, which are similar to those in the present literature. In adult humans in Brazil, the presence of anti- $T$. gondii antibodies varies from 30.34 to $97.1 \%{ }^{(19)(25)}$. However, a higher seropositivity can be found in some Brazilian locations, including the Southwest of the State of MT $(97.4 \%)^{(26)}$. The variability in Brazilian studies might be related to the different cutoff rates and lack of standardized serological techniques, among other factors.

The population of MS has habitual and socioeconomic characteristics that are considered predisposing factors for T. gondii $^{(27)}$.

In addition, analysis of seropositivity from reports of individuals with $T$. gondii indicated that the rates were similar to those found in Brazil ${ }^{(18)(25)}$. For inhabitants of rural areas, such as riverbank populations, seropositivityis reportedly $42.1 \%{ }^{(21)}$.

In university students participating in research in 2010, ELISA detected T. gondii in 39 of 100 participants, with a $95 \%$ confidence interval $^{(18)}$, and a hemagglutination test with a 1:16 dilution resulted in 44 of 145 individuals as positive ${ }^{(19)}$. In both studies, the presence of cats in the student's domicile or contact with these animals was positively correlated with seropositivity in the students.

In the indigenous Terena population of MS, 67 of 256 samples (26.7\%) in 2014 were positive for T. gondii, as detected using the IFAT method with a 1:16 dilution ${ }^{(22)}$. Despite the different populations and difference in sample sizes between this study and the present study, the diagnostic method and dilution were the same; however, the percentage of seropositive samples in the present study was higher.

In other countries, no seropositivity for $N$. caninum was observed in a study in England, with 3,232 people from a serological vigilance program in 2000 and 518 agricultural workers from a population considered to have a high risk of zoonotic diseases, owing to direct contact with possible means of transmission, such as contaminated placenta, fetal fluids, or an environment contaminated with dog feces containing oocysts, who participated in a survey in 1995. Serological reactions were initially tested using ELISA and later using IFAT ${ }^{(17)}$.

In Egypt in 2009 ${ }^{(26)}, 8$ (7.9\%) and $52(51.5 \%)$ of 101 samples from pregnant women at a private clinic in the City of Mansoura tested positive for $N$. caninum and $T$. gondii, respectively. Both parasites were found in $6(5.9 \%)$ samples, and the positive result of $N$. caninum was confirmed using IFAT. Despite the number of samples and differing results, this study confirms the results of the present article, which showed the presence of anti$N$. caninum antibodies in HIV-infected patients, who all presented with concurrent seropositivity for $T$. gondii.

In addition to HIV patients, Lobato et al. ${ }^{(14)}$ also surveyed hemodialysis patients, with seropositivity in 6 of 53 individuals. Two of the positive samples also tested positive for T. gondii; however, these data were not significant for $T$. gondii seropositivity or seronegativity. In MS, $N$. caninum was also reported in a smaller sample of HIV carriers undergoing hemodialysis $(\mathrm{p}<0.05)$.

To the best of our knowledge, this is the first report of anti- $N$. caninum antibodies in immunocompromised humans in MS, resulting in a relatively high seropositivity of $26.1 \%$ when compared with the infection rate of immunocompetent individuals; therefore, this might be an opportunistic infection. Regarding the means of contagion, the presence of anti- $N$. caninum antibodies was found in different animals used for consumption, as well as in dogs, which are its definitive hosts, increasing the possibility of contagion. These initial data for $N$. caninum signal the need to determine if this disease is only an opportunistic disease in immunocompromised persons or if it is a zoonosis.

We believe that this is also the first report of seropositivity for $T$. gondii in immunodeficient persons, with a high seropositivity of $76.4 \%$. The $T$. gondii parasite circulates in immunocompromised patients; because this is a public health issue, broader data about the epidemiology of these parasites is needed, especially in immunocompromised individuals.

\section{ACKNOWLEDGMENTS}

We would like to thank Embrapa Gado de Corte and the Hospital Erasto Gaertner for the support for the research.

\section{CONFLICT OF INTEREST}

The authors declare that there is no conflict of interest. 


\section{FINANCIAL SUPPORT}

Coordenação de Aperfeiçoamento de Pessoal de Nivel Superior (CAPES) and the Conselho Nacional de Desenvolvimento Científico e Tecnológico (CNPq) for the financial support.

\section{REFERENCES}

1. Stark D, Barratt JLN, Van Hal S, Marriott D, Harkness J, Ellis J. Clinical significance of enteric protozoa in the immunosuppressed human population. Clin Micro Biol Rev 2009; 22:634-650.

2. Lazzarotto AR, Deresz LF, Sprinz E. HIV/AIDS e Treinamento Concorrente: a Revisão Sistemática. Rev Bras Med Esporte 2010; 2:149-154

3. Dantas SBA, Fernandes ARF, Souza OL, Mota NRA, Alves CJ, Azevedo SS. Ocorrência e fatores de risco associados às infecções por Toxoplasma gondii e Neospora caninum em cães no município de Natal, Estado do Rio Grande do Norte, Nordeste do Brasil. Cien Rural 2013; 11:2042-2048.

4. Tenter AM, Heckeroth LM, Weiss LM. Toxoplasma gondii: from animals to humans. Int J Parasitol 2000; 30:1217-1258.

5. Bjerkas I, Mohn SF, Presthus J. Unidentified cyst-forming sporozoon causing encephalomyelitis and myositis in dogs. Z Parasitenkd 2004; 70:271-274.

6. Dubey JP, Lindsay DS. A review of Neospora caninum and neosporosis. Vet Parasitol 1996; 67:1-59.

7. Montoya JG, Liesenfeld O. Toxoplasmosis. The Lancet 2004; 363:1965-1976.

8. Lindström I, Kaddu-Mulindwa DH, Kironde F, Lindh J. Prevalence of latent and reactivated Toxoplasma gondii parasites in HIVpatients from Uganda. Acta Trop 2006; 100:218-222.

9. Björkman C, Uggla A. Serological diagnosis of Neospora caninum infection. Int J Parasitol 1999; 29:1497-1507.

10. Vidotto O. Toxoplasmose: Epidemiologia e importância da doença saúde animal. Sem Cien Agr 1992; 13:69-75.

11. Tranas J, Heinzen RA, Weiss LM. Serological evidence of human infection with the protozoan Neospora caninum. Clinic Diagn Laborat Immunol 1999; 6:765-767.

12. Petersen E, Lebech M, Jensen L, Lind P, Rask M, Bagger P, et al. Neospora caninum infection and repeated abortions in humans. Emerg Infect Dis 1999; 5:278-280.

13. Magalhães FB, Jesus EEV, Almeida MAO, Atta AM, Gonçalves MS. Serologic evidences of human Neospora caninum infection in Brazil. In: Meeting of Brazilian Society of Immunology, Salvador. Salvador: Brazilian Society of Immunology; 2002.

14. Lobato J, Silva DAO, Mineo TWP, Amaral JDHF, Segundo GRS, Costa-Cruz JM, et al. Detection of immunoglobulin G antibodies to Neospora caninum in humans: high seropositivity rates in patients who are infected by human immunodeficiency virus or have neurological disorders. Clin Vaccine Immunol 2006; 13:84-89.

15. Dubey JP. Review of Neospora caninum and neosporosis in animals. Korean J Parasitol 2003; 41:1-16.

16. Nam HW, Kang SW, Choi WY. Antibody reaction of human antiToxoplasma gondii positive and negative sera with Neospora caninum antigens. Korean J Parasitol 1998; 36:269-275.

17. McCann CM, Vyse AJ, Salmon RL, Thomas D, Williams DJL, Mcgarry JW, et al. Lack of Serologic Evidence of Neospora caninum in Humans, England. Emerg Infect Dis 2008; 14:978-980.

18. Figueiredo HR, Favero S, Amendoeira MRR, Cardozo C. Inquérito soro epidemiológico para toxoplasmose e avaliação dos condicionantes para sua transmissão em universitários de Campo Grande, Mato Grosso do Sul. Scientia Medica 2010; 20:71-75.

19. Araújo FRA, Sarti EC, Crocci AJ, Seabra VMS, Amorim JH, Cusinato FQ, et al. Anticorpos contra Toxoplasma gondii em estudantes de medicina veterinária de Campo Grande, MS, Brasil. Cien Rural 2000; 30:1017-1019.

20. Oliveira ALL, Cunha RV, Boia MN, Coutinho SG. Ocorrência do Toxoplasma gondii em recém nascidos na cidade de Campo Grande, Mato Grosso do Sul, Brasil. Ensaios e Ciências 2006; 10:139-150.

21. Murat PG. Identificação de anticorpos anti-Toxoplasma gondii e de fatores associados à toxoplasmose em população pantaneira de Mato Grosso do Sul. Campo Grande. 2011. 89p. (Mestrado em Doenças Infecciosas e Parasitárias). Universidade Federal de Mato Grosso do Sul; 2011. Campo Grande.

22. Borguezan C, Sanches FG, Oliveira JTM, Norberg PRBM, Uriarte MAA, Norberg NA. Soroprevalência de anticorpos antiToxoplasma gondii em indígenas da etnia Terena, Mato Grosso do Sul, Brasil. Rev Cuban Med Trop 2014; 1:66.

23. Locatelli-Dittrich R. Diagnóstico sorológico, isolamento, cultivo e caracterização molecular de Neospora caninum em bovinos leiteiros e em equinos no Estado do Paraná, Brasil. 2002. 184p. (Doutorado em Processos Biotecnológicos). Universidade Federal do Paraná; 2002. Curitiba.

24. Paré J, Hietala SK, Thurmond MC. An enzyme-linked immunesorbent assay (ELISA) for serological diagnosis of Neospora $s p$. infection in cattle. J Vet Diagn Investig 1995; 7:352-359.

25. Benetti AH, Schein FB, Santos TR, Tonillo GH, Costa AJ, Mineo $\mathrm{JR}$, et al. Pesquisa de anticorpos anti-Neospora caninum em bovinos leiteiros, cães e trabalhadores rurais da região sudoeste do estado de Mato Grosso. Rev Bras Parasitol Vet 2009; 18:29-33.

26. Ibrahim HM, Huang P, Salem TA, Talaat RM, Nasr MI, Xuan $\mathrm{X}$, et al. Prevalence of Neospora caninum and Toxoplasma gondii antibodies in northern Egypt. Am J Trop Med Hy 2009; 80:263-267.

27. Ishizuka MM. Avaliação da frequência de reagentes ao Toxoplasma gondii, pela prova de imunofluorescência indireta, em suínos de matadouro do Município de São Paulo. Rev Fac Med Vet Zootec USP 1978; 15:151-154. 